\title{
Notes on the Rearing of Echinoid Larvæ.
}

\author{
By \\ E. W. MacBride, M.A., D.Sc., \\ Professor of Zoology in MeGill University, Montreal.
}

The problem of successfully rearing the larvæ of Echinoidea until they had completed their metamorphosis, has been solved by several naturalists. Agassiz* was able, for three weeks, to keep plutei alive which he had fished from the sea, at the end of which time they sank to the bottom and became young echini. Bury $\dagger$ was able also to rear a few of the plutei of one of the Neapolitan species through the whole of their larval life, and finally Théel $\ddagger$ has published an account of how he obtained all stages in the development of Echinocyamus pusillus from the result of artificial fertilisation.

During the months of May and June in both 1898 and 1899, I was occupied with a similar, though not identical problem. I wished to obtain sufficient material of all the stages of development of Echinus esculentus to enable me to make an exhaustive investigation of the formation of all the organs of the adult Echinus. For this purpose it was not sufficient to be able to rear one or two specimens through the metamorphosis; the question was to be able to obtain a considerable number of late and metamorphosing stages. This end was finally attained in July, 1899, twenty-four young echini and a large number of plutei, with an advanced rudiment of the echinus within them, were obtained.

Reviewing the history of two seasons' experiments, it seems possible to arrive at some idea of the conditions for the healthy life of these larvæ, and for the sake of future investigators these are outlined here.

The greatest number of experiments were made with Echinus

* Revision of the Echini, L. Agassiz.

+ According to a statement made to the author in 1894.

\# "The Development of Echinocyamus pusillus," by H. Théer. Proceedings of the Royal Society of Sweden, Upsala, 1892. 
esculentus, but for the sake of comparison, cultures of the larvæ of Echinus miliaris were also prepared.

The first condition for a healthy experiment is that only full-sized and perfectly ripe individuals of both sexes should be used for fertilisation. It is generally possible to get a few eggs capable of fertilisation from unripe individuals, but the resulting plutei are feeble, and soon die.

The fertilisation is best performed in a large square glass dish; a small quantity only of spermatozoa must be added to the clean seawater with which the dish is filled. The ova are added in sufficient quantity to make a single layer over the bottom. A piece of boltingsilk of medium mesh will permit the ova to pass, but will keep back pieces of ovary, and to a large extent unripe ova.

The laboratory at Plymouth is provided with bolting-cloth of mesh exactly suitable to the eggs of $E$. esculentus. The unripe eggs appear to be surrounded by a thick, glassy membrane (entirely distinct from the membrane formed after fertilisation), which prevents their passing through the meshes of the silk.

After fertilisation, the water full of spermatozoa must not be allowed to stand more than twenty minutes before it is decanted off, and during the first twenty-four hours the water covering the eggs should be frequently changed.

Next in importance to the proper choice of individuals for the experiment is the selection of a proper source whence the sea-water is to be obtained. Water obtained close inshore is perfectly useless. The plutei will live for at most a week in it. In Plymouth, water must be brought from outside the Breakwater, and only this water must be employed for both fertilisation and the subsequent culture.

At the end of twenty-four to thirty hours, all the eggs which are developing normally will have reached the blastula stage, and have risen to the surface. They must then be decanted off into culture jars. The jars which I used at this stage in the experiments were of a deep bellshape, and of a capacity of two gallons. Each was fitted with a Browne plunger. This invaluable apparatus has already been described elsewhere. It is sufficient here to notice that by means of it the water in the jars is kept in constant though gentle agitation, and the formation of a surface film of dust, bacteria, etc., effectually prevented.

The jars must be carefully guarded from direct sunlight, which soon proves fatal to the larvæ. They must be covered in as much as is consistent with the free motion of the plunger, and the water ought to be changed to the extent of one-third of its bulk every day. This is effected by temporarily stopping the action of the plunger, when the healthy larvæ will come to the top. The bottom water can then be 
siphoned off. It is advisable to have a small amount of a filamentous alga, such as Ectocarpus, floating in the water. Ulva, and other leaflike forms, are more apt to decay, and then foul the water.

After the lapse of about eight to ten days, it will usually be seen that in one or two of the jars, development is proceeding normally, whereas in the others, symptoms of unhealthiness have appeared. The healthy larvæ are then transferred to larger culture jars, in which they complete the remainder of their development. The jars used for this purpose by me had a capacity of ten gallons, and each was fitted with a large plunger. Not more than 250 larvæ should be placed in each jar, and as before, the water should be changed to the extent of one-third of its bulk daily.

It may seem to many that the course of proceedings which I have sketched out is a very roundabout one. Why, it may be asked, should not 250 blastulæ be transferred directly from the dish in which fertilisation is effected to the larger jar? The answer is, that this course has been tried and it failed. In a word, it is not possible for the experimenter to discriminate between larvæ which have vigour enough to complete their development and those which will soon die, until the second week of their existence. We must, in the first instance, allow natural selection to weed out the weaker. In this connection a curious fact may be mentioned. A very successful result was obtained from a culture of larvæ proceeding from a fertilisation carried out very badly. The eggs were piled on one another, several layers deep, and the water remained full of spermatozoa all night. As a result, only about 10 per cent. or less of the eggs became blastulæ. But those which survived showed remarkable hardiness, and from them young echini were obtained.

Echinus esculentus and Echinus miliaris are decidedly different in colour, size, and general appearance, and it is not therefore surprising to learn that their larvæ are different in every period of existence, as has been detailed in a paper in the Quarterly Journal of Microscopical Science (vol. xlii., 1899, p. 335). Here it need only be mentioned that the larva of E. miliaris has only four ciliated epaulettes, and that the young echinus at metamorphosis has one pair of tube feet in each interradius, in addition to the azygous tentacle. The pluteus of $E$. esculentus on the other hand has six ciliated epaulettes, which eventually coalesce in order to form two circular bands of cilia, and the young echinus has at first only the azygous tentacle in each interradius.

The necessity for such frequent changes of sea-water seems to arise rather from lack of food than from lack of oxygen, and it is more urgent in some years than in others, according to variations in the amount of vegetable plankton. In 1898 it did not seem so necessary, 
and in that year there were great quantities of Halosphaera in the water. I did not realise until late in 1899 that such a quantity of water should be added each day; had I done so earlier, my success might have been even greater than it was. The fact was brought to my attention by observing that plutei went on living in an apparently healthy manner, but that the rudiment of the echinus within them either failed to increase in size, or was actually resorbed.

It appears to me likely that the difficulty experienced in rearing many marine larvæ is largely that of finding food; for there appears to be no reason why they should require more oxygen per day than do the yolky eggs of other species in which development is direct, and goes on with great rapidity.

In conclusion, I have to express my gratitude to my friends Mr. E. J. Allen, the Director of the Station, and Mr. E. T. Browne, of University College, London, for much assistance and advice.

Zoological Laboratory, McGill Univeritit, Montreal, October 9, 1899. 